\title{
ANALYSIS OF THE EMERGENCE OF BARRIERS TO DEVELOPMENT OF SOCIAL INNOVATIONS. THE CASE OF SENIOR NGOS
}

\author{
Piotr WERYŃSKI ${ }^{1 *}$, Dorota DOLIŃSKA-WERYŃSKA ${ }^{2}$ \\ ${ }^{1}$ Silesian University of Technology, Faculty of Organization and Management; piotr.werynski@ polsl.pl, \\ ORCID: 0000-0001-9334-5048 \\ ${ }^{2}$ Silesian University of Technology, Faculty of Organization and Management; \\ dorota.dolinska-werynska@polsl.pl, ORCID: 0000-0001-8466-5867 \\ * Correspondence author
}

\begin{abstract}
The paper raises the problem of structural, cultural and agency barriers that limit the development of social innovations in the selected Silesian senior non-governmental organizations. The morphogenetic scheme is presented in terms of explaining the roots of the emergence of ressentimental mechanisms and effects determining the course of social innovations. On this basis and using qualitative analysis of data obtained during focus group interviews (FGI) with the leaders and members of NGO's, a diagnosis and explanation is conducted concerning the occurrence of ressentimental tensions in the processes of initiating, testing and implementing innovation.
\end{abstract}

Keywords: social innovation, non-governmental organizations, ressentimental mechanisms and effects, morphogenetic cause analysis, FGI qualitative analysis.

\section{Introduction}

Joseph Schumpeter (1960), a precursor of scientific reflection on innovativeness, already wrote about social implications of innovations. However, social sciences only took up systematic research on social effects of innovation at the beginning of the twenty-first century (Mulgan et al., 2007; Bukowiecki et al., 2012). An increase in interest in these issues can be tied, in the economic dimension, with the consequences of the financial and economic crisis emerged after the year 2009 (Wronka-Pośpiech, 2015). It resulted in an even greater focusing of attention on the role of creativity, innovativeness, including social innovativeness, in the support of sustainable economic growth, creation of safe workplaces, increasing the competitiveness of the societies in Western countries, that are struggling with, among others, the issue of aging population. In the social dimension there is an ongoing process of 
empowering wide social circles, activating groups that until now have been excluded from social and civil life. A key role in increasing agency of elders, people economically marginalized (unemployed for a long time, homeless), ethnic, religious or sexual minorities is played by non-governmental organizations. It takes place particularly where the current activation models fail, are outdated or do not allow a proper use of possibilities appearing in the environment. Among these areas are: education (including permanent education), healthcare, protection from degradation of the natural environment, public services or city planning (architectural barriers).

Therefore the authors of the paper, aware of the existing trends and economic, social and demographic needs, took up the issue of structural, cultural and agency barriers restricting the development of social innovations in the selected senior non-governmental organizations.

Which conditions support the creation of ressentimental tensions, more precisely determining the ressentimental mechanisms and effects in non-governmental organizations? According to the assumptions of Max Scheler's (1997) concept of group ressentiments, it can be accepted that the situation of the following ressentimental concepts occurring: (1) social tensions, e.g. on economic, ethnic, cultural grounds, in the access to technology and digital competencies, cultural goods and/or between groups of interest within the organization, (2) specific thought systems justifying social, cultural and economic inequalities, (3) derivative types of interactions, exalting some at the expense of others with (4) existing legal or organizational regulations, formally making everyone equal, result in that the group ressentiments restrict the actions leading to the organizational change (ressentimental effects). The aforementioned conditions create ressentimental barriers within the organization and in its environment.

In order to take up the root cause analysis of the rise of group ressentiments as well as of relevant ressentimental effects, resulting in dysfunctions in the area of innovativeness, understood in a broad sense, in non-governmental organizations as well as in their environment, the authors refer also to the assumptions of morphogenetic theory and to critical realism. Critical realism assumes that the reality of the examined phenomena and social processes is not only reflected in its empirical nature, but mainly in its causality. Causal mechanisms are real, stemming from the relations existing between the social entities, from the relations between properties, forces of social and cultural structures and the agency capabilities of individual and group subjects. The aforementioned causal forces are not of necessary character (Archer, 2003, p. 36). Not all mechanisms tied with the relevant structures or social actors are activated in the morphogenetic processes.

The actions of ressentimental structural and cultural contexts should be treated as causal forces, that can only partially be subjected to a direct empirical observation. Depending on the configuration of the aforementioned contexts and the character of interactions between them and the agency of social subjects, there are causal forces that are inactive in the given context and time, and can be activated (emerged) in a different configuration of the environmental 
factors. In case of accepting the presented epistemological assumption as well as the methodological directive stemming from it, one should search for relationships, relations between the sphere of contexts and agency in the temporal diachronic order.

The state of ressentimental contexts and the work of ressentimental effects can be examined if their complex status as the effects of multi-level (micro-, meso- and macro-) and dualistic, objectivist (structure) - subjectivist (agency) reality is taken into consideration. Within the reality two different types of causal forces are operating (Archer, 2013, pp. 311-316). In order to diagnose and seek its genesis as well as the directions of conditioning of the contemporary organizational behaviors, the authors used, taking into consideration the diachronic temporal and causal order, research procedures, characterized with the use of the qualitative method (focused group interview - FGI) and the morphogenetic root cause analysis. The aforementioned procedural approach makes it possible to analyze the elements of structural and cultural properties of the given organization as well as agency capabilities of organizational subjects.

The basic research questions were asked: (1) What structural barriers, cultural barriers and agency barriers restrict the initiating, testing and implementing of social innovations in the analyzed environments and in non-governmental organizations? (2) In what way do the ressentiments (fixed negative group emotions) condition innovative activities within the organization (explain causal mechanisms)?

\section{Social innovation - many definitions and constituting features}

The research on innovation and innovativeness is usually associated with technical and technological innovations or, in a broader depiction coming from the classicist of scientific reflection on innovation - Josef Schumpeter (1960, p. 104), with new products, services, new processes, innovative organizational or marketing solutions. Attention should also be paid to innovation allowing a creative reaction to social challenges, among others, connected with the situation on the labor market of the socially excluded, impact of air pollution on health of local societies, or social effects of globalization of many economic activities. These are social innovations, which in practice mean such solutions that at the same respond to social needs and trigger a permanent change in the particular social groups. Such solutions may be connected to the use of innovative products, processes, organizations or marketing ideas too, what in result should enable a different solution to typical social problems. This way of defining social innovation can be found in OECD, determining that it does not refer to the introduction of new types of production or utilization of new markets due to their economic potential. Its main objective is to satisfy the new needs that the market is not able to satisfy, or to create new, 
more gratifying ways of activation, offering workplaces to people and changing their roles in the production process (OECD, 2011).

European Commission in Guide to Social Innovation defines on a wide scale that this is social in both, goals and resources. Innovation should be open to territorial, cultural differences etc. It should be social in terms of process, that is participation of future users and recipients of innovation as well as in terms of socially expected objectives. Their source is the creativity of citizens, non-governmental organizations, local communities, entrepreneurs, state and local council clerks. The purpose of such innovation is to provide opportunities, both for public sector and for markets, product, service and model development, so that their implementation would meet an individual and collective aspiration more effectively (European Commission, 2013). The aforementioned understanding of social innovation is the foundation of operational utilization. It was referred to, among other, by the report authors: The perspectives of social innovation development in Masovia (2015). As social innovation the activity/model/service was qualified, showing at least 3 out of 8 features: inter-sector character, openness and cooperation, presumption and co-production, interdependence, creation of new social roles and relations, rank-and-file character, effective utilization of sources and resources, development of new resources and opportunities (Kośnicki 2015, p. 18).

The National Centre for Research and Development (NCBiR) in the Social Innovation Programme conceptualizes the notion of social innovation on a similarly wide scale ${ }^{1}$. It includes both, socially justified technical and technological innovations as well as strictly social innovations. To the category of technical and technological innovations, socially justified, such solutions are qualified that are connected with the adjustment of a given product to the needs of special recipients, for example, residents of the regions with poorly developed infrastructure or struggling with a permanent low-stack emission of smog of carbon origin. However, the category of strictly social innovations encompasses such solutions that concern, among others, the problems resulting from an increasing number of people who are at a retirement age, disable, long-term unemployed, that is the underprivileged groups, in need of state and society's support, also suffering from tensions on the labor market, connected e.g. with the increase of well-educated people, who cannot find work despite good qualifications. The aforementioned intermediary Institution, regardless of the forms of activities adopted, advises in all the projects including social innovations in NCBiR programmes to indicate a clear social context, to define a problem that should be solved and to indicate a cause-and-effect relationship between the project and the social problem being solved (http://www.ncbr.gov.pl/...).

In the definitions of social innovation a fundamental thesis is expressed that it is tied to the total change of functioning of the social system: with reorganizing elements (reconfiguration) or incorporating new units into it, what translates into an increase of effectiveness. In turn, effectiveness is defined as the ability to meet social needs, which in this context should be understood as the needs related to the functioning of the society, not only in the local or regional dimensions, but also as a whole, e.g. through the ability to recreate resources or to keep the 
social and cultural cohesion. This element is emphasized particularly strongly in the definition by the researchers from the Center at the Stanford University, according to which 'social innovation is any useful solution to a social need or problem, which is better than the currently used approach' (in the meaning: more effective, efficient, permanent or just) and creating value more beneficial to the society as a whole than to private units. In other words, social innovation transforms an operating system in such a way that not only it becomes more effective but it also improves its efficiency (the ability to coordinate actions).

An important definition attribute determining the emergence of social innovation is also relativizing it to the specific place. Innovation becomes social innovation only when it is introduced to a new environment, when it is used, utilized, accepted and when it contributes to solving specific problems as well as meeting the needs of a given community (Conger, 2003).

A decisive role in the social innovation is always played by the users, social innovations are always designed together with the users. Employees, customers, citizens - not only do they inform about their needs, as in the traditional innovation management, but they also participate in solving problems, developing new products, services or institutions. All of the aforementioned ways of defining more or less directly refer to the idea of common good (Merton, 2002), of those who diagnose the problem, initiate and test its solution, implement, validate and, in the end, utilize new ideas in the social life.

The overview of definitions shows that there is no commonly accepted definition, but everyone agrees that there are common elements: creative changes in social processes, relations between people (so-called society for innovation is created); various types of innovation (diversity of solutions) may emerge in various forms, with various reactions towards them. They constitute a tool to fight with global and local social problems. For many researchers and practitioners of social innovation the thing that differentiates these innovations from others is transforming the social systems. Social innovation cause: changes in the way of society operating (Mulgan et al. 2007, p. 22) and changes in solving social problems in a way that may require significant and permanent shifts of, e.g. resources. Success occurs when the ideas change the mentality of people - thanks to a series of actions of practitioners, beneficiaries and public opinion (Mulgan, 2007, pp. 22-23), and also when ideas change the institutional procedures, rules, regulations, flows of power, beliefs (Westley, 2008).

As it was mentioned, one can distinguish a few features of social innovations differentiating them from product, organizational, process or marketing innovations. Social innovations are social actions, which are a permanent realization of, in certain circles or groups of certain axiological assumptions, more or less determined idea of progress, idea of common good, needs or social well-being. They are spread through a wider, than in other types of innovations, range of diffusion channels: through information services, marketing techniques, logistics, social media, social movement, through lobbying for introducing certain formal and legal regulations, foundations and associations, through charismatic people, local authorities, social entrepreneurs, spontaneous and rank-and-file activities of the participants of a civil society. 
Social innovations concern the interdisciplinary issues. In the course of implementing, testing and spreading their products or final services they require crossing the organizational borders of the given institution, borders of the sector or scientific discipline, which usually does not take place in case of technological innovations. Furthermore, their execution requires new social interactions, relations between people, diversified environments, groups and organizations up to this point, not cooperating with one other. This type of innovation integrates their creators, users and recipients, changes its social and economic environment according to the accepted preliminary assumptions. They are often tied to the concept of reform, as they refer to various problems that the society should strive to solve if it wants to survive. These problems are, among others, ecological, financial, educational, related to crime, corruption, keeping peace etc. (Zacher, 1998, pp. 311-312). The aforementioned feature is emphasized in a particular way by the portal of the European Social Fund - innowacjespoleczne.org.pl. It defines in a short and precise way, in operational sense, that social innovation is the 'search for even better, novel solutions responding to social needs, for the repair of even a small segment of reality. Social innovation differs from innovation of other types by the fact that its objectives as well as utilized means are social, (...) created by people, for people and with people' (https://www.innowacjespoleczne.org.pl/...).

In the summary of the previous considerations regarding definitions and terms one should present a convention of defining social innovation, that was accepted for the research presented. A pragmatic approach to truth lies at the base of the author's operational definition of the term of social innovation. Pragmatically understood theory of truth accepts something as true when it checks out through its consequences, especially the practical ones (James, 2001, pp. 200-217). The understanding of truth above is close to identifying it with efficiency, effectiveness and indirectly with the adequacy of meeting needs of the people in a specific situational context. Pragmatists search for the criterion of truth in experience, daily life, consequences of actions taken. Truth is not an unchanging category, it becomes, verifies itself in the effects of social actions. Pragmatically understood social innovation emphasized the significance of effects of social actions, the significance of activities aimed at action research, that is research, action and cooperation (Greenwood, and Lewin, 1998; Chrostowski, and Jemielniak, 2008). The aforementioned perspective of social innovation covers the diagnosis of reality, pointing out the problem, initiating, testing, implementing and possibly validating the final outcome of innovation (i.e.: product, service, model), which as a result leads to a permanent and, to a significant degree, predicted change in the specific environment, social group, organization. It is achieved through cooperation and mutual inspiration of innovators, users and recipients. 


\section{Research methods and techniques}

The basic research method is a morphogenetic cause analysis. Its deductive, analytical scheme constitutes the methodological frames, a pattern of systematizing data. They serve for the analysis of roots and duration of detailed ressentimental effects in the examined environment as they a result of, implicit to a greater or lesser extent, often socially unaware determining mechanisms.

The elements of author scheme of causal explaining for the analysis of particular cases of the impact of ressentimental mechanisms among the members of the given non-governmental organization:

1. Emergent structural conditions (group interests) exist, that differentiate the members of organizations and institutions in regards to an access to power, wealth, prestige. Following Scheler (1997), it may be continued that, within the frames of the aforementioned conditions, all rights (civil, employee, social) are formally guaranteed. However, the life of an organization, actual practice, remains in contradiction with the official legislation, accepted organizational regulations.

2. Emergent cultural conditions (sets of standards and values, organizational cultures) exist, which validate the structural conditions, legitimizing at the same time the relations of exalting some subjects and demeaning others.

3. Structural and cultural tensions create ressentimental contexts for individual and group reactions. The greater difference between a legal, formal group prestige in an organization and the balance of forces in the organization, the bigger potential of ressentimental tensions.

4. Structural and cultural ressentimental contexts determine agency of individual and group action subjects in the organization.

5. The action subjects process the external ressentimental conditions internally (emotionally, reflexively), through a mechanism of internal conversation, on the point of contact of two aforementioned contexts and individually configured concerns (motivations).

6. Depending on the type of reflexivity adopted (communicative, autonomic, metareflexive, fractured reflexivity) by the subjects in the organization and the feeling of continuance or discontinuance of the action contexts, the subjects in a different way execute their agency in relation to the external conditions (Archer, 2003, pp. 342-361; 2007). Innovative activities are promoted by the type of autonomic reflexivity (criticism towards the environment leading to action) and, to some degree, of meta-reflexivity (criticism towards oneself and environment, leading to system change). 
7. The subjects interact adversely to the organizational structural and cultural conditions, creating collective action subjects (with a capability of agency) inside the organization. The interactions of the members of such groups, in relation to the primary action subjects (with a limited agency) are a manifest of tension existence and an expression of ressentimental mechanisms.

8. Ressentimental effects, emerged in the organization, constitute an effect of group overwork (by collective action subjects at the expense of primary action subjects) of the relations between the forces of agency and structural-cultural forces.

9. In what conditions does the existing balance of structural-cultural and agency forces contribute to the organizational morphostasis? The agreement amongst the main collective action subjects related to the existing relations between the structural context (group interest) and cultural one (dominating ideas and values) or acceptance of the existing tensions between the structural and cultural context blocks the development of new collective action subjects, that is inter-group interactions leading to the creation of new collective action subjects - status quo organizational change.

10. In case of organization remaining in the state of morphostasis, the existing ressentimental structural and cultural contexts are usually limited to the creation of inter-organizational innovations, but they also block their participation in innovative ecosystems.

11. In what conditions does the existing balance of cultural-structural and agency forces lead to organizational morphogenesis? A lack of agreement amongst the main action subjects (possessing agency) in terms of the existing balance of forces between the structural and cultural contexts, or the creation of new collective action subjects (new difference of interests, new ideas and values), which question the existing balance of structuralcultural forces, leads to organizational morphogenesis. At the same time, the number of primary action subjects decreases, who are deprived of agency.

12. In the state of organizational morphogenesis, ressentimental structural and cultural contexts facilitate the creation of innovative ecosystems. In result, ressentimental tensions lead to organizational change, appearance of new collective action subjects and ecosystems positively stimulating the course of innovative processes in various organizational practices.

The identification of cognitive and axiological perspectives of the aforementioned action subjects will be helpful in the diagnosis of these contexts. It should manifest in the confrontation of two views of the organizations' world, assigned to two types of subjects and in the indication, for each of them, of specific causal forces that determine their agency capability. An individual cognitive perspective concerns the primary action subjects, who 'have no voice in the process of transforming structure and culture. They neither express interests, nor organize themselves in order to achieve strategic goals'. In this social category one may list the circles not participating in the life of their local societies, they stay out of the game of interests and ideas, and in the organization structure they are deprived of agency capability. The perspective of 
association concentrates on group action subjects. In the organization, they possess agency capability in the management processes (Archer, 2013, pp. 265-266).

In order to examine the characterized problem above, also a qualitative interview method was used. To be precise, a technique of focus group interviews (FGI) was adopted. In FGI research 36 people took part, both leaders (board members) and members of senior non-governmental organizations. The selection of particular focus groups had a deliberate character. The representatives of three senior non-governmental environments were subject to research; rural environment (from commune Nędza, near Racibórz), small town environment (from Łazy, near Zawiercie) and town environment of Mysłowice. The focus group interview was conducted in each environment separately. Additionally, in focus groups the equal per cent of representatives of local Third Age University and appropriate per cent for the given territorial Commune/Town Senior Council was assured. It was also assumed that, according to the rules of grounded theory (Konecki, and Chomczyński, 2012, pp. 285-287; Hensel, and Glinka, 2012, pp. 89-113), all data gathered in separate groups were compared with one another in a continuous way, and next, the ordering and interpreting codes were distinguished for the research material from FGI.

\section{Diagnosis and root cause analysis of barriers in the examined senior organizations}

The processes of implementing innovation in non-governmental organizations are conditioned by complex factors of external as well as of internal character. Barriers constitute a part of them, being defined as forces opposing initiating and developing innovation. The authors of the thesis Barriers to Social Innovation (Mendes et al., 2012) distinguished two groups of barriers in the innovation processes: structural barriers and agency barriers. Structural barriers are related to the complexity, uncertainty of social processes as well as their effects, they also concern political, cultural and economic contexts. The aforementioned groups of structural barriers were adjusted in the paper to the category of ressentimental contexts (Weryński, 2018).

1) Social context: complexity of the problem, unpredictability of side effects, strong components of binding, not bridging, social capital, gaps in the access to information and uncertainty related to the influence of innovation in the future, lack of strict ex post data and the possibility of validating the products of innovation;

2) political and cultural contexts: monopolization of political power, restrictions of free communication, freedom of speech and media, 'top-down' approach when formulating and implementing policies and strategies, lack of legal and cultural recognition, 
inadequate system of public orders, culture oriented at the workings of state institutions, not social ones, poor knowledge transfer policies;

3) economic context: restriction capabilities of independent financing of initiatives, too expensive innovations, lack of mechanisms of scaling innovation, potentially high number of subjects, actions and technologies that will be negatively influenced by innovation, nature of public goods, which are the result of innovation (Mendes et al, 2012, p. 28).

The three contexts of structural barriers occurrence, presented above, constituted a reference point for diagnosing restrictions in the development of social innovation, which were noticed by the researchers from three environments. They structuralized the reports from research.

All leaders and members of the examined environments and senior organizations consider the main structural barrier to be the restricted capabilities of acquiring financial means for the realization of its grassroots initiatives, often independent from the local governmental authorities. In Nędza commune (3 thousand residents), Racibórz county, there is a thriving Third Age University (Uniwersytet Trzeciego Wieku - UTW), Senior Council, Association of Active Women and their Families, which can be considered to be a specific phenomenon, because many cities cannot boast having such organizations active. The members of UTW from Nędza, when asked about what main barriers they perceive in the nearest environment, respond, that these are financial problems. 'Financial deficits, unfortunately, if we had a bit better financing, we might have done somewhere something more. But we don't have, unfortunately. We get everything by ourselves. The commune only gives us the location and nothing more. But it is still a big help. The problems we face are, for example, the transport, costs of transport which prevent us from making many trips' (economic context: financial restrictions).

Similarly, the surveyed people from $\mathrm{Lazy}^{2}$, a town with approximately 7 thousand residents, in Zawiercie county, mention financial aspects and the lack of infrastructure, that prevent them from accepting new members as the greatest barrier in running their activity. The support from the authorities is not sufficient, therefore the seniors acquire projects on their own. They point out that it stems from the existing political, environmental divisions, as a result of unequal treatment of non-governmental organizations in town. 'We gain funding, the commune gives us currently only objects, no funds, so we have to look for sponsors' - opinion of an examined person. 'This year we have received only 2 thousand PLN and we should have got at least 10 thousand. Association of Rural Women and Christians get this money. It is unjust as it is us who create the whole senior policy in town, thanks to us the Senior Council was created' (economic context: financial restrictions and social: components of binding, not-bridging social capital).

On the other hand, UTW or Senior Council leaders from Mysłowice - a medium-sized Silesian town - point out barriers related to digital exclusions of many members and sympathizers. According to those examined objective financial restrictions exist, making it impossible to organize computer courses for everyone willing. Many of them do not use the 
internet, cannot afford newspapers and thus, do not have access to information (economic context: financial restrictions and partially political and cultural contexts: poor knowledge transfer policies).

However, a significant group of structural barriers is made by the political and cultural contexts which often occur syndromatically with economic and social conditions. Among the leaders and members of UTW from Nędza, diverse opinions concerning the question how they are perceived in the local environment - were noted. Some claim that they are perceived in a very positive way. Others notice that they are treated 'like the fifth wheel on the car'. According to this group majority, reaching the agreement with Ms. Mayor as well as the Council of the Commune is difficult. 'There is no will to create Senior Council. Even though documents have been submitted... in a very detailed way, with good justification, but there is no understanding from the councilmen. It is a factual organizational barrier' (political and cultural contexts: 'top-down' approach while formulating and implementing policies and strategies).

The existence of a serious barrier of structural character - a political condition - was also noted by the examined activists from Mysłowice. They emphasized the fact of a lack of permanent agreement with city government authorities - for four years the city has not given a location for the operations of Senior Council of the commune' (political and cultural context: culture oriented at the operations of state institutions, not social ones).

The examined seniors are aware of the need for acquiring funds for their further activities. The barrier is that they cannot, unlike the UTW in Nędza commune which doesn't have the status of an association, try to acquire such funds on their own. 'It means, we ourselves cannot submit such projects. Only through the Commune Culture Centre. (...) Acquiring in such a way is very difficult and cumbersome, it is a very small town. There are no super-experts here who could run the matter. In total, we submitted seven projects, with one project being successfully completed and which is executed, that is <Wealth of herbs $>$ in Nędza, a garden was created' (economic context and cultural context: poor knowledge transfer policies).

Furthermore, the examined leaders of UTW in Mysłowice point out that the local authorities sometimes try to engage senior leaders in the current politics, to instrument them. There are social divisions with the environment that result in UTW candidate being on many different election lists for the County Council and in that way no one wins. 'The leaders receive a proposition. So we sometimes use it too, we get a proposition to pull some lists. That is the truth, that if the leader has people behind him, so it is sometimes played not in the way it should. We aren't as good at such politics. Unfortunately, we have been used as the drive wheel of the campaign. Instead of one candidate we had four on four different lists and no one got into the council'. 'And in the county they keep giving us some small amounts of money-500, 1500 PLN. Being there we can have the strength of the voice and take part in dividing the budget. That means to have our representative there' - one of the leaders states. Between the interest groups within the organization one can observe a lack of mutual trust. It is difficult to clearly choose 
one leader, and a couple of them has political ambitions (social context: lack of bridging social capital and political and cultural context: 'top-down' approach when formulating and implementing policies and strategies, lack of legal and cultural recognition).

Agency barriers, or to be more precise, related to agency, concern in equal measure the behaviors of participants within the organization as well as in its environment. In the subject literature the most commonly used is the conceptualization of the term of agency, suggested by Anthony Giddens (2003). Agency is defined as a possibility of causing actions by a specific subject, with the simultaneous assumption that in every moment it has the possibility to take different actions. Archer defines the term of agency further, it does not restrict it only to the activities of the action subject. She believes that the constitutive feature of agency is not only the ability of the subject acting but his very existence (Archer, 2013). The authors claim, according to Archer's way of defining agency, that the very existence of the organization or integrated senior environment is the manifestation of the agency of its participants.

Barriers related to the actions occurring in the process of implementing innovations, pointed out in the thesis Barriers to Social Innovation to: reluctance towards innovations, insufficient utility of innovations, small alternativeness of innovations compared to other solutions, small efficiency of innovations, divergent group and individual interests, state of people's minds, personal relations between people (envy), lack of trust towards innovators, lack of approval from the environment for the joint approach to changes caused by innovations, lack of intermediary connecting partners in social networks, lack of networks in the communities, lack of skills in many areas of social life, including the skill of developing institutional entrepreneurship, protectionism and aversion to risk, problem with oversight and coordination (Mendes et al, 2012, p. 28).

Which of the aforementioned types of agency barriers occur, according to those examined, in their environment and organizations? The researched members of senior organizations feel as they are the members of a collective action subject, which possessed agency capabilities in its environment. The researched seniors from UTW Łazy consider themselves to be social leaders in their towns, who, for example, propagate an ecological, active lifestyle. 'We are those, who integrate all generations. We organize actions from kindergarten to Third Age, we've been planting trees for 10 years together with the forest inspectorate, grandmas take their grandchildren there. Guardians come from the kindergarten (...). We've planted about 600 trees with different results'. 'Our university is one out of ten universities in Poland cooperating with the foundation The Earth and People'. 'We are angry with town authorities that they build Lazy of concrete. There is another big tree clearance planned and we collect signatures to block the clearance' (distrust towards innovators, lack of agreement from the environment towards common attitude to changes brought by innovations).

To the question what social groups in their communes could feel as the leaders of public opinion, commune elite, carriers of cultural patterns - the surveyed from Nędza answered that it is not them, but the association 'Active women'. This association is subsidized financially, 
promoted and socially connected with the members of Commune Council. It is noticed that this fact triggers conflicts in the commune and rivalry for money (political and cultural context: 'top-down' approach when formulating and implementing a policy, strategy, social context: a component of binding social capital, agency barrier: divergent group interests, interpersonal envy).

The examined activists, when asked to provide examples of social innovation in their organizations, pointed out consistently that these are all activities with the purpose of the improvement of quality of life. The people with the highest agency degrees, who initiate, supervise, test, implement social innovations, both in rural environment (Nędza) and small town ( Łazy), are their leaders - UTW ${ }^{3}$ chair, according to those examined. They indicate that, thanks to their activity, creative thinking and determination, the members of UTW have access to learning German, English, dance course, meeting with a lawyer. When asked to indicate the traits of a leader they mention: 'Our chair is responsible, patient, always right and inspire crowd' - says one of the research participants from Nędza. The very chair, when asked about the traits of social innovation leader, claims that it is 'the one who should work in a group, get involved in the works for the organization, its members and should delegate responsibility as well as cooperate with a democratically selected board (...). The board should include someone responsible for culture, a secretary, treasurer, or a person responsible for promotion and visualization (..)' (agency barriers: lack of skills in many areas of social life, including the skill of developing an institutional entrepreneurship, state of initiators' minds, innovation co-creators).

It is clearly indicated, in the opinion of the examined organization members and the chair, that a key role in the implementation of social innovation is possessed by the leader - a strong group front man with great authority, person respected by the group and able to make independent, sometimes even authoritative, decisions.

Those examined where asked what determines that the organization is innovative? The seniors from $z$ Nędza answered that it depends on the ability of continuous learning, development and ability to use the resources from external environment (agency barrier: people's state of mind, agreement or lack of agreement in the environment regarding a common attitude towards changes triggered by innovation). As an example of such activities - lectures are indicated, when the chair invites interesting people, academic lecturers, specialists on EU funds, what allows gaining new knowledge on a regular basis. Innovativeness of their organization is also assessed based on a variety of the proposed alternatives to seniors '... it is dance school, fitness, sightseeing trips, chess section, computer classes'. Innovativeness also consists in developing cooperation with other senior organizations, what allows a permanent exchange of experiences and good practice (agency barrier: existence of, to a limited extent, or a lack of network in the communities). 
Social innovativeness is also understood as a co-responsibility for common good, those excluded and wronged. The leaders from UTW in Łazy see the need to represent their interests. 'In the times of PRL (Polish People's Republic, up to 1989) people had their fields taken away for poor extras to their retirement benefits, now they belong to the state and lie fallow. People don't know that they can try to get their land back, which now belongs to a commune and it is heard that the commune sells it. It would be the university's role to organize a training for such people' (agency barrier: lack of knowledge and skills in many areas of social life).

The barriers limiting social innovation from the area of agency refer to interpersonal relationships, their complexity and intensity, tensions and conflicts inside the organization, determining the range of contexts (tensions) and ressentimental effects. They come from an everyday, inevitable contact of every members of organization, occurring separately regardless of the functions served by them, often in organizational structures not clearly specified in functional terms. They come into action when competencies overlap, during personal and group rivalry, fractions in perceiving and emphasizing group interests, when initiating and implementing innovations, often being in opposition to the particular group or environmental interests.

Above a diagnosis and categorization was conducted, concerning the barriers existing in the mind of those surveyed in connection with the particular contexts. In the final part of the paper, a root cause analysis will be made on the way how ressentimental mechanisms and effects work in a chosen environment and non-governmental organization (UTW Mysłowice).

UTW was established by The Cardinal August Hlond University of Education in Myslowice as an independent organization, with neutral philosophy of life, open to various ideas and paradigms. The idea of an open university was executed by a pluralistic, consensual and rankand-file choice of theme for lectures and lecturers. The executed program strategy by the UTW Board resulted in high frequency during the lectures, trainings and integration events. After a few years, the patronage over UTW and the whole infrastructure of the University of Education was taken by the Jesuit Order. A subsidiary of Ignatianum Academy was set up. Since that time, according to those examined, a lot has changed at the University. The speakers claim that these days the representative of the Academy authorities decides for seniors about the selection of lecturers and themes of classes. They were given worse classrooms (in the basement).

One of the UTW Board members speaks about a new relation in this way: 'In the period of political campaign one of the lectures raised the topic of abortion. So that is no topic for us, seniors. It was a campaign on a philosophy of life. It was in a very bad taste. Many people walked out of the classroom'. The number of UTW participants and members started to decrease systematically. Additionally, a ressentimental tension was magnified by the fact of an outright support of Ignatianum Academy by town authorities, leading to blockage of autonomous activities of UTW, pluralism of non-governmental organizations in Mysłowice. It should be resolved with the political option in force, as emphasized by the participants of 
focus group interview. 'Seniors are treated there at the University a bit at a disadvantage, as I don't understand the fact, being in the Board, that people should go down to the cellar'.

In the examined environment the elements of ressentimental context appeared. Social tensions started to increase on the grounds of the philosophy of life and culture between two groups, collective action subjects, both within the frames of UTW Board and among the members. The conflicting factor within the groups was the attitude towards the religious institution supervising their activity. The new situation of ownership by the partner university and UTW started to legitimize the relation of exalting some members of the organization and marginalizing others. A dissonance occurred between a formally equal status of all members of the organization and the actual balance of forces in the organization, resulting in the increase of ressentimental tensions. New structural and cultural ressentimental contexts started to determine agency of action subjects in the organization.

However, in analogy to the conception of positive functions of conflict by Lewis A. Coser (2009), in the organizational life one may find positive functions of ressentiments, which are an effect of tensions in the structure and/or culture of the researched organization. Negative emotions, for example the feeling of envy close to ressentiment, in a situation of a lack of acceptance for an innovator in his organization, for the potential creator of innovation, generates a need to omit the mechanisms of social control, institutional and personnel barriers, limiting his development possibilities. Similarly, the fear of disturbing the existing balance of interests among the members of the examined organization, which is formally sanctioned by e.g. using an increased control of his organizational behavior, magnifies the ressentimental emotions of a potential innovator. Among those, who have not left the organization yet, a mechanism of dual axiological awareness, doublethink and valuation works - an official and private one. Due to them, the autonomous action subjects go over their interactions emotionally and reflexively in a ressentimental organizational context. Next, they take a decision about migrating to a new environment, open to the introduction of social innovation. The mechanism of change acceptance works as a negation of previous state.

When the examined organization remains in the state of maintenance of the existing ressentimental structural and cultural context, it limits the creation of innovation inside the organization and blocks the participation in innovative ecosystems. Currently, those examined, who represent the majority of the recent UTW members, see the need to establish the second UTW, more pluralistic, democratic and with open philosophy of life. 'Something is totally off base, something is wrong here that people come and after some time they state say it is not for them, they don't like it'. 


\section{Conclusions}

As a result of the analysis of qualitative data from focus group interviews (FGI), the types of structural barriers and agency barriers were diagnosed, negatively conditioning initiating, testing and implementing social innovation in the analyzed environments and nongovernmental organizations, that were identified by leaders and members of three senior NGOs. In the area of structural barriers, more precisely of economic context, FGI participants emphasized above all the weight of financial restrictions. Among social barriers the existing components of a binding, non-bridging social capital as well as interpersonal and group envy were decided to be the most serious ones. The existence of the 'top-down' approach while formulating and implementing the policies and strategies, a lack of legal, cultural recognition, poor knowledge transfer policies, culture oriented towards the actions of state institutions as opposed to social ones, were deemed to be the most significant barriers from the political and cultural context. Furthermore, those examined pointed out the restrictions of agency conditioned by divergent group interests, states of minds of innovation implementers and users, lack of trust towards the innovators, including negative emotions - envy, lack of agreement from the environment towards a joint approach to changes created by innovations, lack of knowledge and skills in many areas of social life, existence in a restricted area or lack of network in their communities.

If one would relate the types of structural and agency barriers diagnosed above during the implementation of social innovation, to the six stages of the innovation process provided in the 'Open book of Social Innovation' (Murray et al, 2012): inspiration, proposition, prototype, maintenance, scaling and system change, it has to be stated that most often those examined are inspirers themselves, then the creators of the propositions of change, simulation and prototypes, executed in small scale, e.g. of residential areas. Later, they gradually extend the scale of operations up until actions moving outside the city, region and country (casus of UTW Sports Olympics and Senior Organizations in Łazy). The biggest difficulties are caused by scaling the effects of their innovations, though most often they measure the effects of their innovation by the number of new members. Another problem is making permanent system changes, which often require institutional, financial and expert engagement of the local government authorities.

A root cause analysis of the action of ressentimental mechanisms and effects was also conducted, conditioning innovative actions in the given environment and non-governmental organization. Ressentimental effects, arising in the state of organizational change, for example taking an approach of accepting changes as the negation of the current state and in the state of persistence - double axiological and migration consciousness, constitute an effect of emotional and reflective overworking, performed by the entities subjected to the ressentimental actions as well as the effect of its feedback reaction (agency) in the organizational social and cultural conditions. 
The results of the presented research allow an assertion that the tensions, ressentimental barriers inhibit the progress of social innovations in the examined senior non-governmental organizations. On the other hand, successfully initiating, testing and implementing of rank-andfile social innovations leads to the decrease of ressentimental tensions in the organization.

\section{Acknowledgments}

The research was conducted within the frames of the project 'Social innovation as the third mission of university' (NCBiR), which is executed under a supervision of Piotr Weryński from 1 December 2018 to 28 February 2021, according to Activity 3.1 'Competencies in Higher Education' in Priority Axis III PO WER, execution of 'Third Mission of University'. The purpose of the project is to improve competencies (enabling knowledge and skills extension related to the creation of social innovation, digital competencies, social communication) of 252 leaders and members of senior organizations (177 women and 75men) aged 60+ from 21 local circles (towns and municipalities) of Silesian voivodship. A result of the project will be an increase of the level of their social and civil engagement, improvement of the representativeness of their interests in local and regional politics.

\section{References}

1. Archer, M. (2003). Structure, Agency and the Internal Conversation. Cambridge: Cambridge University Press.

2. Archer, M. (2007). Making our Way through the World. Human Reflexivity and Social Mobility. Cambridge: Cambridge University Press.

3. Archer, M. (2011). Morphogenesis: Realism's Explanatory Framework. In: A. Maccarini, E. Morandi, and R. Prandini (Eds.), Sociological Realism. New York: Routledge.

4. Archer, M. (2013). Człowieczeństwo. Problem sprawstwa. Karków: Zakład Wydawniczy NOMOS.

5. Bednarczyk, I., Trzeciak, S., and Śledź, D. (2015). Perspektywy rozwoju innowacji społecznych na Mazowszu - raport końcowy. Warsaw-Olsztyn: Instytut Badań i Analiz Grupa Olsztyńska Szkoła Biznesu.

6. Bukowiecki, A., Rudnicki, S., and Strycharz, J. (2012). Społeczny wymiar innowacji. Zarzadzanie Publiczne, 2(20), 13-23.

7. Chrostowski, A., and Jemielniak, D. (2008). Action research w teorii organizacji i zarządzania. Organizacja $i$ Kierowanie, 1(131). Retrieved from 
https://www.researchgate.net/publication/255564948_Action_Research_w_teorii_organiz acji_i_zarzadzania, 18.10.2018.

8. Conger, S. (2003). A List of Social Inventions. The Innovation Journal, http://www.innovation.cc/books/conger-book-table.htm, 26.11.2018.

9. Coser, L.A. (2009). Funkcje konfliktu społecznego. Seria WTS, Tom 5. Kraków: Nomos.

10. European Commission (2013). Guide to social innovation. Retrieved from http://s3platform.jrc.ec.europa.eu/, 15.07.2019.

11. Giddens, A. (2003). The Constitution of Society: Outline of the Theory of Structuration [Stanowienie społeczeństwa. Zarys teorii strukturacji]. Cambridge: Polity Press.

12. Greenwood, D.J., and Levin, M. (1998). Introduction to Action Research. London: Sage Publications Inc.

13. Hensel, P., and Glinka, B. (2012). Teoria ugruntowana. In: D. Jemielniak (Ed.), Badania jakościowe. Podejścia i teoria (pp. 89-113). Warsaw: PWN.

14. http://www.ncbr.gov.pl/programy-krajowe/innowacje-spoleczne/, 2019.

15. https://www.innowacjespoleczne.org.pl/innowacje-spoleczne, 2018.

16. James, W. (2001). Pojęcia filozoficzne a praktyczne wyniki. In: H. Buczyńska-Garewicz (Ed.), James William (pp. 200-2017). Warsaw: Wiedza Powszechna.

17. Jędrych, E., and Szczepańczyk, M. (2017). O potrzebie innowacji społecznych w kształceniu ustawicznym Polaków (Lifelong Learning). Kwartalnik Naukowy Uczelni Vistula, 1(51), 69-81.

18. Konecki, K., and Chomczyński, P. (2012). Słownik Socjologii Jakościowej. Warsaw: Difin.

19. Kwaśnicki, W. (2015). Innowacje społeczne - nowy paradygmat czy kolejny etap w rozwoju kreatywności człowieka? In: W. Misztala, G. Chimiak, and A. Kościański (Eds.), Obywatele wobec kryzysu: uśpieni czy innowatorzy? (pp. 23-59). Warsaw: IFiS PAN.

Mendes, A., Batista, A., Fernandes, L., Macedo, P., Pinto, F., Rebelo, L., Ribeiro, M., Ribeiro, R., Sottomayor, M., Tavares, M., and Verdelho, V. (2012). Barriers to Social Innovation. Retrieved from http://www.tepsie.eu/images/documents/tepsie.d3.1barriers tosocialinnovation.pdf, 19.09.2018.

20. Merton, R. (2002). Social Theory and Social Structure [Teoria socjologiczna i struktura społeczna]. Warsaw: PWN.

21. Mulgan, G., Tucker, S., Ali, R., and Sanders, B. (2007). Social Innovation - What it is, why it Matters. How it Can be Accelerated. Oxford: The Young Foundation.

22. Murray, R., Caulier-Grice, J., and Mulgan G. (2010). Open book of Social Innovation, Young Foundation. Retrieved from https://youngfoundation.org/wp-content/uploads/ 2012/10/The-Open-Book-of-Social-Innovationg.pdf, 16.09.2018.

23. Novikova, K., and Wiśniewska, M. (2017). Creation and innovation in selected theories of social sciences and humanities. Journal of Modern Science, 3(34), 59-78. Retrieved from https://www.researchgate.net/publication/321389770_Tworczosc_a_innowacja_w_swietle _wybranych_koncepcji_w_naukach_spolecznych_i_humanistycznych, 15.07.2019. 
24. OECD/Eurostat (2008). Oslo Manual. Guidelines for Collecting, Reporting and Using Data on Innovation. Warsaw; Paris: OECD Publishing; Luxembourg: Eurostat.

25. Pearce, C.L., and Conger, J.A. (2003). Shared Leadership: Reframing the Hows and Whys of Leadership. Thousand Oaks: Sage Publications Inc.

26. Rogers, E.M. (2003). Communication of innovations: a cross-cultural, approach. New York: Free Press London.

27. Scheler, M. (1997). Ressentiment im Aufbau der Moralen [Resentyment a moralnośćc] Warsaw: Wyd. Czytelnik; Frankfurt: Klostermann Vittorio Gmbh.

28. Schumpeter, J.A. (1960). Theorie der wirtschaftlichen Entwicklung [Teoria rozwoju gospodarczego]. Warsaw: PWN.

29. Weryński, P. (2018). Konteksty resentymentalne jako otoczenie innowacji. Przegląd Organizacji, 12, 41-49.

30. Weryński, P., Dolińska-Weryńska, D., and Tokar, J. (2014). Zarzadzanie innowacjami w sektorze MŚP. Warsaw: Difin.

31. Westley, F. (2008) The social innovation dynamic. Retrieved from http://sigeneration.ca/ blog/wp-content/uploads/2010/07/TheSocialInnovationDynamic.pdf, 15.07.2019.

32. Wronka-Pośpiech, M. (2015). Innowacje społeczne - pojęcie i znaczenie. Studia Ekonomiczne, Zeszyty Naukowe Uniwersytetu Ekonomicznego w Katowicach, 212, 124-136.

33. Zacher, L.W. (1998). Innowacja. In: Z. Bokszański (Ed.), Encyklopedia socjologii, Tom 1. Warsaw: Oficyna Naukowa.

\section{Footnotes}

${ }^{1}$ Social innovations were operationally accepted in the current budget perspective (2014-2020) by the EU institutions as a fifth type of innovation, next to four others standardized earlier in Oslo Manual (2008). This definition is permanently functioning within the frames of policy and programs by European Commission, e.g. in, European program of combating poverty and social exclusion, Innovation Union, Social Business Initiative, Employment and social investment package, Digital Agenda, New Industrial Policy, European Innovation Partnership in the field of active and healthy ageing, Cohesion Policy (Wronka-Pośpiech, 2015).

${ }^{2}$ Third Age University has been operating there energetically for 11 years. Within it there are 11 thematic sections functioning, among others: sailing, model-making, art, photography or cabaret, water and Olympic sections. 170 members. They organize the International Senior Olympics, which is visited each year by around 3 thousand participants from Poland, Europe and other continents. 
${ }^{3}$ In the environment of Mysłowice's organizations, the innovation introduction is conducted in a more collegial, partner way, the leaders present a more democratic management style of an organization. Such management style mostly results from a greater participation, than in the remaining environments, of people with higher education in the board of organization and Senior Council. 